\title{
The development of ISO 9000 certification and the future of quality management
}

\section{A survey of certified firms in Hong Kong}

Received November 1996 Revised A pril 1997
International Journal of Quality $\&$ Reliability Management, Vol. 15 No. 2, 1998, pp. 162-177 (c) M CB University Press, 0265-671X

\author{
Tat Y. Lee
}

University Industrial Centre, T he University of Hong Kong, Hong Kong

\section{B ackground}

Between the inception of ISO 9000 in 1987 and December 1995, nearly 130,000 ISO 9000 certificates have been issued in 99 countries (Symonds, 1996). These figures, both the number of certificates issued and the number of countries participating, have been constantly increasing. Together with this development, the following questions have arisen (Wenmoth and Dobbin, 1994):

- W hat companies, in terms of trade and size, are involved in ISO 9000 certification?

- What are the reasons for certification?

- What are the benefits and limitations of ISO 9000?

- Is ISO 9000 certification the end of the quality journey?

- What are the key factors in quality improvement?

A questionnaire survey was conducted by the University Industrial Centre of the University of Hong Kong in August 1996 with a view to providing answers to these questions in relation to the Hong Kong environment.

The target respondents were ISO 9000 certified firms in Hong Kong. A II the certifying bodies operating in Hong Kong were requested to supply the details of the firms certified by them. Some firms were certified by more than one certifying body. However, each certified firm was sent one questionnaire only, duplication was eliminated. The questionnaire was sent to 640 firms and 235 completed questionnaires were received by the deadline. The findings are discussed in the following sections.

\section{Classification of certified firms}

The certified firms were asked to identify the category of business for themselves. A II respondents fell into one of the three industrial sectors, namely, manufacturing, service, and construction. Manufacturing firms included those in electronics, electrical, plastics, toy, food, watch and printing industries. Service firms operated in such businesses as management consulting, software, stockholding, container terminal operations, shipping agency, in-flight catering, 
public utilities and banking. Construction firms were relatively straightforward, because the majority of them were in the construction, civil engineering and building industries.

A ccording to the returned questionnaires, 86 firms, i.e. 37 per cent of the respondents, were from manufacturing, 57 (24 per cent) from service and 92 (39 per cent) from construction. The data are shown in Table I. In the late 1980s and early 1990s, many industrialists considered ISO 9000 more suitable for the

Development of ISO 9000 certification manufacturing industry. Currently, there is little doubt about the adaptability of the standard to different industries. The wide spectrum of trades which participated in the survey confirms that certification is not confined to any specific industrial sector.

\begin{tabular}{|c|c|c|c|c|c|c|c|c|c|}
\hline \multirow{2}{*}{$\begin{array}{l}\text { Number } \\
\text { of staff }\end{array}$} & \multicolumn{2}{|c|}{ Manufacturing } & \multicolumn{2}{|c|}{ Service } & \multicolumn{2}{|c|}{ Construction } & \multicolumn{2}{|c|}{ Total } & \\
\hline & & $(\%)$ & $(\mathrm{N})$ & $(\%)$ & & $(\%)$ & (N) & $(\%)$ & \\
\hline $1-50$ & 13 & 15 & 18 & 32 & 31 & 34 & 62 & 26 & \\
\hline $51-100$ & 9 & 10 & 8 & 14 & 20 & 22 & 37 & 16 & \\
\hline $101-500$ & 28 & 32 & 17 & 30 & 27 & 29 & 72 & 30 & \\
\hline $501-1,000$ & 11 & 13 & 8 & 14 & 8 & 9 & 27 & 11 & Table I. \\
\hline 1,001 and above & 25 & 29 & 6 & 10 & 6 & 6 & 37 & 16 & Distribution of company \\
\hline Totals & 86 & 100 & 57 & 100 & 92 & 100 & 235 & 100 & size in the 1996 survey \\
\hline
\end{tabular}

This survey addressed the issue of the size of certified firms. It is interesting to note that a similar survey was conducted by the same author in 1994 (Lee, 1995). For both surveys, the number of employees were segmented in groups of from 1-50, 51-100, 101-500, 501-1,000, and 1,001 and above. The firms were grouped under manufacturing, service and construction sectors in both surveys. The relevant data for 1994 are shown in Tablell.

In the 1994 survey, questionnaires were sent to 137 certified firms of which 61 responded. In the 1996 survey, 640 questionnaires were sent out and 235 completed questionnaires were returned. Taking all certified firms into account,

\begin{tabular}{|c|c|c|c|c|c|c|c|c|c|}
\hline \multirow{2}{*}{$\begin{array}{l}\text { Number } \\
\text { of staff }\end{array}$} & \multicolumn{2}{|c|}{ Manufacturing } & \multicolumn{2}{|c|}{ Service } & \multicolumn{2}{|c|}{ Construction } & \multicolumn{2}{|c|}{ Total } & \\
\hline & & $(\%)$ & $(\mathrm{N})$ & $(\%)$ & & & (N) & $(\%)$ & \\
\hline $1-50$ & 3 & 19 & 4 & 21 & 7 & 27 & 14 & 23 & \\
\hline $51-100$ & 4 & 25 & 4 & 21 & 5 & 19 & 13 & 21 & \\
\hline $101-500$ & 5 & 31 & 6 & 32 & 11 & 42 & 22 & 36 & \\
\hline $501-1,000$ & 3 & 19 & 3 & 16 & 2 & 8 & 8 & 13 & Table II. \\
\hline 1,001 and above & 1 & 6 & 2 & 11 & 1 & 4 & 4 & 7 & Distribution of company \\
\hline Totals & 16 & 100 & 19 & 100 & 26 & 100 & 61 & 100 & size for the 1994 survey \\
\hline
\end{tabular}


IJQRM

15,2

164

the proportion of small and medium firms appeared to be quite stable. For example, 23 per cent of the certified firms employed between 1 and 50 employees in the 1994 survey and the corresponding figure was 26 per cent in 1996.

The number of certified firms which employed more than 1,000 people increased in 1996. In 1994 only 7 per cent of firms in this category were certified but the figure increased to 16 per cent in 1996. The change took place as a result of more large manufacturing firms (employing more than 1,000 people) being certified. In the 1996 survey, 29 per cent of the certified manufacturing firms employed more than 1,000 people, while the corresponding figure in 1994 was only 6 per cent. In real terms, 25 large manufacturing firms were certified in the 1996 survey compared to only one in the 1994 survey.

A mong the 25 large manufacturing firms, one produced furniture; one produced garments; one produced metal products; three produced toys and the remainder produced electrical and electronic products. The largest manufacturing firm employed 11,000 people and manufactured electrical products. With the exception of two firms, all large manufacturing firms had set up major production and related operations in China.

It has become popular for manufacturers in Hong Kong to set up manufacturing facilities in China since the mid-1980s. The labour and land costs in China are much lower than in Hong Kong. In order to maintain control of operations and quality of product, many manufacturers have implemented ISO 9000 in their operations in China. This may explain why an increasing number of manufacturers implement the quality assurance management standard.

\section{Reasons for certification}

E ach certified firm was asked to state the main reason for certification. The following three answers were available for the firm's choice:

(1) The customer demanded the firm to become certified to ISO 9000.

(2) The firm considered that it had to be ISO 9000 certified in order to stay in business.

(3) The firm wanted to use ISO 9000 to improve the management system.

The first answer reflected a more immediate reaction to the customer's demand for certification. The second answer showed that the firm predicted or expected that the customer would eventually demand certification. A Iternatively, the firm might be under the indirect pressure from competitors who had been certified. The third answer indicated that the firm wanted to use the standard to improve the management of operations.

The respondents were also allowed to put down any other reasons. However, each firm was asked to name the main reason only. In the data analysis process, any firm ticking more than one answer was counted separately. Table III summarizes the feedback from all the firms. 


\begin{tabular}{|c|c|c|c|c|c|c|c|c|c|}
\hline \multirow{2}{*}{$\begin{array}{l}\text { Reasons } \\
\text { for } \\
\text { certification }\end{array}$} & \multicolumn{2}{|c|}{ Manufacturing } & \multicolumn{2}{|c|}{ Service } & \multicolumn{2}{|c|}{ Construction } & \multicolumn{2}{|c|}{ Total } & ISO 9000 \\
\hline & & $(\%)$ & (N) & $(\%)$ & (N) & $(\%)$ & & $(\%)$ & certification \\
\hline \multicolumn{10}{|l|}{ To satisfy } \\
\hline \multirow{2}{*}{$\begin{array}{l}\text { demand } \\
\text { To stay in } \\
\text { business }\end{array}$} & 10 & 12 & 3 & 5 & 36 & 39 & 49 & 21 & 165 \\
\hline & 22 & 26 & 15 & 26 & 30 & 33 & 67 & 29 & \\
\hline \multicolumn{10}{|l|}{ To improve } \\
\hline management & 41 & 48 & 30 & 53 & 9 & 10 & 80 & 34 & \\
\hline $\begin{array}{l}\text { More than one } \\
\text { answer/others }\end{array}$ & 13 & 15 & 9 & 16 & 17 & 18 & 39 & 17 & $\begin{array}{l}\text { Table III. } \\
\text { Reasons for certification }\end{array}$ \\
\hline Totals & 86 & 100 & 57 & 100 & 92 & 100 & 235 & 100 & (all firms) \\
\hline
\end{tabular}

Taking account of all the firms in the three industrial sectors, one third (34 per cent) of the firms obtained ISO 9000 with a view to improving management. This was mainly shared by manufacturing and service firms in that nearly half of the firms named this as the main reason for certification. A s discussed above, manufacturing firms that had set up operations in China tended to use the ISO 9000 standard to improve their management and control of the operations there.

Unlike the manufacturing firms, almost all service firms were operating in Hong Kong. Thirty of the 57 service firms implemented ISO 9000 with a view to improving management of their operations. The businesses of these firms included public utilities (telecommunication, transportation, town-gas and government departments), banking and medical laboratory service. Some of these firms implemented the standard in one department and then expanded to other departments. This showed that they were satisfied with the standard.

A high proportion (39 per cent) of the construction firms were driven by their customers to become certified. In addition, a third (33 per cent) of the firms in this sector considered that they had to be ISO 9000 certified in order to stay in business. In recent years the housing authority and some other government departments in Hong Kong awarded contracts to ISO 9000 certified contractors only. M any construction firms were "forced" to become certified and some of them did not have a proper quality assurance management system before adopting ISO 9000.

It was suspected that small and medium firms were customer driven in ISO 9000 certification. The findings of this survey tended to support this argument. Three service firms reported to be customer driven and two of them employed less than 50 people. For the construction firms, 14 of the 36 customer-driven firms employed less than 50 people. In the manufacturing sector, 20 per cent of the firms employing less than 50 people reported to be customer driven. This was not as obvious as in the other two sectors (see Table IV).

In summary, the survey results indicated that ISO 9000 was implemented for different purposes in different industries. For manufacturing firms, the majority 


\begin{tabular}{|c|c|c|c|c|c|c|c|c|c|}
\hline \multirow{3}{*}{$\begin{array}{l}\text { IJQRM } \\
15,2\end{array}$} & \\
\hline & \multirow{2}{*}{$\begin{array}{l}\text { Reasons } \\
\text { for } \\
\text { certification }\end{array}$} & \multicolumn{2}{|c|}{ Manufacturing } & \multicolumn{2}{|c|}{ Service } & \multicolumn{2}{|c|}{ Construction } & \multicolumn{2}{|c|}{ Total } \\
\hline & & & $(\%)$ & $(\mathrm{N})$ & $(\%)$ & & $(\%)$ & & $(\%)$ \\
\hline \multirow[t]{3}{*}{166} & $\begin{array}{l}\text { To satisfy } \\
\text { customer } \\
\text { demand }\end{array}$ & 2 & $20^{\mathrm{a}}$ & 2 & 67 & 14 & 39 & 18 & 37 \\
\hline & $\begin{array}{l}\text { business } \\
\text { To improve }\end{array}$ & 2 & 9 & 6 & 40 & 13 & 43 & 21 & 31 \\
\hline & $\begin{array}{l}\text { management } \\
\text { More than one }\end{array}$ & 7 & 17 & 7 & 23 & 1 & 11 & 15 & 19 \\
\hline Table IV. & $\begin{array}{l}\text { answer/others } \\
\text { Totals }\end{array}$ & $\begin{array}{r}2 \\
13\end{array}$ & 15 & $\begin{array}{r}3 \\
18\end{array}$ & 33 & $\begin{array}{r}3 \\
31\end{array}$ & 18 & $\begin{array}{r}8 \\
62\end{array}$ & 21 \\
\hline
\end{tabular}

Notes: apercentage value $=$ number of firms in this category/corresponding number of firms in Table III $=$ $2 / 10=20$ per cent

of them aimed at using ISO 9000 to improve the management and control of their operations. It was quite common for them to use the ISO 9000 system to assist the management and control of production and associated operations in China. W hile using ISO 9000 to improve the management of operations was the main objective in the service sector, small and medium firms in this sector tended to be customer-driven. The main reason for construction firms to obtain an ISO 9000 certificate was to meet the customer's demand.

\section{Benefits of certification}

The certified firms implemented ISO 9000 for different reasons. One might wonder if ISO 9000 would bring along any benefits in addition to merely a certificate. Tw elve points of the questionnaire were related to the benefits of ISO 9000 certification. The findings related to these points are discussed under the headings of "internal operations", "customer relations" and "subcontractor relations".

Internal operations

Other studies, conducted in several North A merican, European and A sian countries, have suggested that ISO 9000 will benefit the internal operations of the certified firm (Lee, 1997). The questionnaire listed five points of benefits relating to daily operations for the respondents to supply feedback on the benefits gained. The five benefits were:

(1) better team spirit

(2) less staff conflict

(3) reduced wastage

(4) increased efficiency

(5) shorter lead time. 
The respondents were allowed to tick more than one benefit. They were also allowed to put down other benefits. The percentage shown in Table $\mathrm{V}$ was the ratio of the number of firms ticking the benefit to the total number of firms in the group. For example, 68 of the 86 manufacturing firms, namely 79 per cent, reported to have achieved the benefit of getting better team spirit. Similarly, 235 firms returned the questionnaires and 170 (72 per cent) reported improvement in team spirit. This was the biggest benefit reaped by the certified firms. Taken as a project, the ISO 9000 certification process would involve a large number, if not all, of the staff who might not have had a chance to work together so closely on a common topic before. In this process a better team spirit was generated.

Development of ISO 9000 certification

\begin{tabular}{|c|c|c|c|c|c|c|c|c|c|}
\hline \multirow{2}{*}{$\begin{array}{l}\text { Benefits of } \\
\text { certification }\end{array}$} & \multicolumn{2}{|c|}{ Manufacturing } & \multicolumn{2}{|c|}{ Service } & \multicolumn{2}{|c|}{ Construction } & \multicolumn{2}{|c|}{ All } & \\
\hline & & $(\%)$ & (N) & $(\%)$ & & $(\%)$ & $(\mathrm{N})$ & $(\%)$ & \\
\hline \multicolumn{10}{|l|}{ Better team } \\
\hline Less staff & & & & & & & & & \\
\hline $\begin{array}{l}\text { conflict } \\
\text { Reduced }\end{array}$ & 58 & 67 & 34 & 60 & 44 & 48 & 136 & 58 & \\
\hline wastage & 60 & 70 & 28 & 49 & 49 & 53 & 137 & 58 & \\
\hline Increase & & & & & & & & & Table V. \\
\hline $\begin{array}{l}\text { efficiency } \\
\text { Shorter lead }\end{array}$ & 60 & 70 & 42 & 74 & 57 & 62 & 159 & 68 & $\begin{array}{l}\text { B enefits gained with } \\
\text { respect to internal }\end{array}$ \\
\hline time & 35 & 41 & 22 & 39 & 24 & 26 & 81 & 34 & operations \\
\hline
\end{tabular}

A total of 58 per cent of the firms agreed that there was "less staff conflict" as a result of certification. Before the quality assurance management system was formalized, people might argue on the working procedures and the distribution of responsibilities. However, the staff conflicts would be reduced if the ISO 9000 system was adequately developed.

The benefit of "reduced wastage" was reported by 58 per cent of the respondents. ISO 9000 emphasizes the management of the process. Since the process was clearly defined by the procedures, the mistakes made in the process would be minimized. This was a positive factor in reducing wastage. Further improvement might be achieved through providing quality and technical training to employees to arouse quality consciousness. Some people argued that the reduction in wastage was a result of the Haw thorne effect (Mukhi et al., 1990). However, it could be further argued that the Hawthorne effect was achieved by implementing ISO 9000 !

The next benefit recorded was "increased efficiency". A high percentage (68 per cent) of the firms reported to have achieved improvements in efficiency. It was commonly agreed that ISO 9000 focused on the management system in that efficiency might be improved through adopting more reasonable working procedures. 
IJQRM

15,2

168

The benefit of reducing lead time received the lowest score. Only a third (34 per cent) of the firms agreed that they had achieved "shorter lead time". This appeared to be quite natural because ISO 9000 is concerned with the management of processes much more than the use of technology. Shorter lead time might be achieved easier with the adoption of new technologies and equipment, which was out of the scope of ISO 9000. Some authors have suggested other management strategies such as re-engineering (Hammer and Champy, 1993). How ever, the extensive use of information technology is an important factor of this approach. A company does not have to adopt the latest technologies for ISO 9000 certification. This might explain why the certified firms could not reduce the lead time. A comparison of different quality management philosophies is discussed elsewhere (Lee, 1996).

The above discussion refers to the data of all the certified firms which took part in this survey (Table V). The benefits derived by the construction firms were generally less than the manufacturing firms. Considering the fact that a large proportion of the certified construction firms pursued certification under customers pressure, one might suspect that the firms which were passive in adopting ISO 9000 reaped less benefits from the system.

\section{Customer relations}

The issue of customer relations was addressed in this survey. The following four questions were identified and the respondents were asked to determine if they had:

(1) improved sales through attracting new customers;

(2) obtained longer/bigger contracts with existing customers;

(3) received less control from the existing customers; and

(4) received fewer complaints from the existing customers.

A total of 62 per cent of the firms in the three industrial sectors reported to have improved sales and attracted new customers (see T able VI). The corresponding figure in the 1994 survey conducted by the author was only 30 per cent. This change might suggest that more customers were aware of ISO 9000 and they would choose a certified company wherever possible.

Only 25 per cent of the respondents reported that their existing customers had signed longer/bigger contracts with them. The percentage of firms experiencing less control from their customers was also as low as 30 per cent. A further review of the completed questionnaires showed that five of the ten manufacturing firms which were customer-driven did not get longer/bigger contracts from the existing customers, neither did they experience less control from the existing customers. This situation was also true for the service firms. Three service firms were customer-driven and two of them did not get longer/bigger contracts or less control from their existing customers. As far as the construction firms were concerned, 31 of the 36 construction firms which were customer-driven reported not having longer/bigger contracts or less 


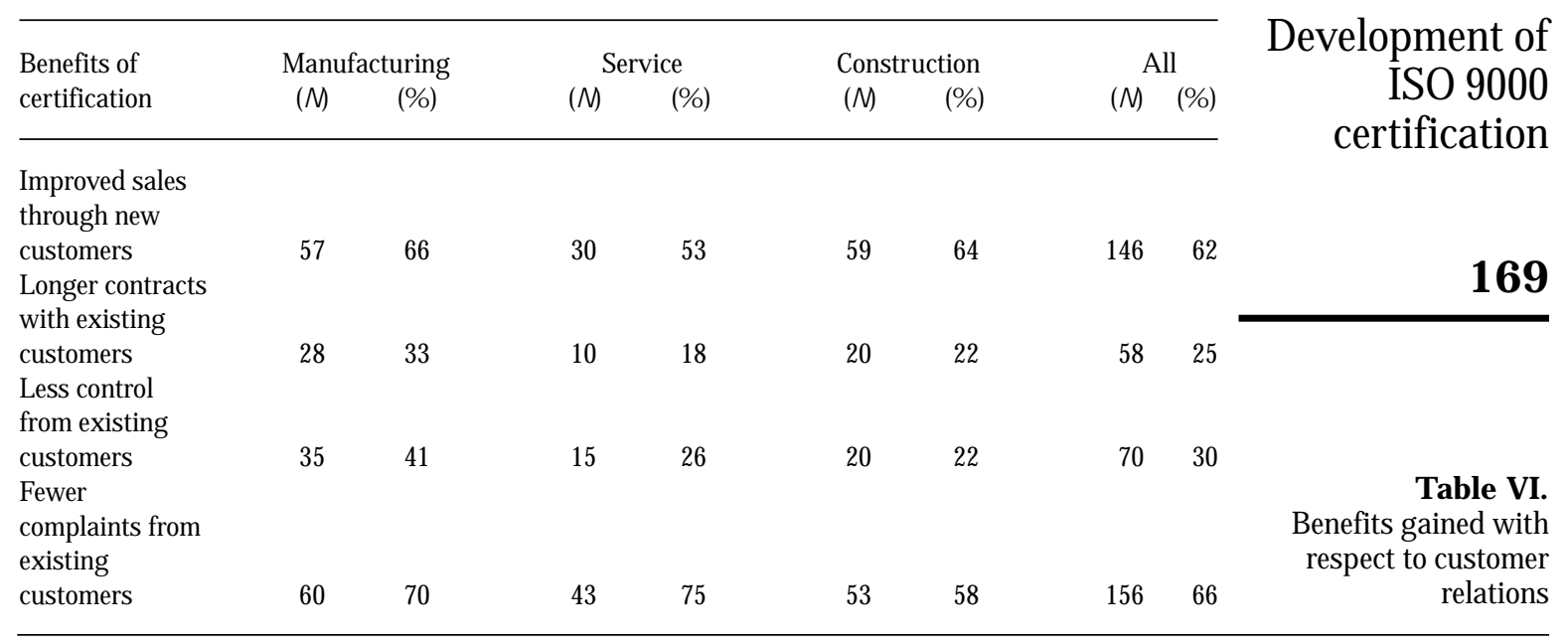

control from their existing customers. These figures strongly suggested that if a firm did not take the initiative to become ISO 9000 certified and waited until the customer demanded it, the firm should not expect a longer/bigger contract or less control from its existing customers even after it was certified. This might be true at least for the short term.

A total of 66 per cent of the firms reported receiving fewer complaints from their customers after they were certified. This was the biggest benefit reported by the certified firms, including a high percentage of the firms which were customer-driven. The reduction in customer complaints might have been achieved through implementing proper procedures to the processes or instituting tighter quality control on the product or service. In the context of quality assurance management, the approach of implementing proper procedures is preferred. However, in industrial reality, the approach of instituting tighter quality control is often the first step taken by the ISO 9000 certified firms which do not have a solid quality management background. Fortunately, certified firms were able to derive the benefit of fewer customer complaints regardless of the approach taken.

Subcontractor relations

The control of subcontractors is an important element of ISO 9000. This study tried to find out in what way the relationship between the firms and their subcontractors would be affected in the ISO 9000 certification exercise. Three points were addressed in the survey. The firms were asked if the following situations took place after they were certified:

- Did the firms request the subcontractor to become certified too?

- Did the firms build up better relations with the subcontractors?

- Did the firms impose more stringent/formal evaluation schemes on the subcontractors? 
IJQRM

15,2

170

Table VII summarizes the feedback. The data showed that only 22 per cent of the certified firms demanded the subcontractors to be certified to ISO 9000. This indicated that it was uncommon for an ISO 9000 certified firm in Hong Kong to impose the requirement on the subcontractors. In fact, many firms would ask the subcontractors to obtain certification only when their customers so demanded.

\begin{tabular}{|c|c|c|c|c|c|c|c|c|}
\hline \multirow{2}{*}{$\begin{array}{l}\text { Benefits of } \\
\text { certification }\end{array}$} & \multicolumn{2}{|c|}{ M anufacturing } & \multicolumn{2}{|c|}{ Service } & \multicolumn{2}{|c|}{ Construction } & \multicolumn{2}{|c|}{ All } \\
\hline & (N) & $(\%)$ & (N) & (\%) & & $(\%)$ & $(\mathrm{N})$ & (\%) \\
\hline \multicolumn{9}{|l|}{$\begin{array}{l}\text { Subcontractors } \\
\text { to become }\end{array}$} \\
\hline $\begin{array}{l}\text { certified } \\
\text { Better relations } \\
\text { with }\end{array}$ & 21 & 24 & 14 & 25 & 17 & 18 & 52 & 22 \\
\hline subcontractors & 40 & 47 & 31 & 54 & 28 & 30 & 99 & 42 \\
\hline $\begin{array}{l}\text { More stringent } \\
\text { control over }\end{array}$ & & & & & & & & \\
\hline subcontractors & 64 & 74 & 43 & 75 & 53 & 58 & 160 & 68 \\
\hline
\end{tabular}

In order to satisfy the requirements of ISO 9000, particularly Clause 4.6 of ISO 9001 and ISO 9002, many certified firms implemented new evaluation schemes on their subcontractors instead of asking them to become certified. The evaluation schemes were generally more stringent and formal than before the firms were certified. A total of 68 per cent of the certified firms reported to have taken this approach.

A total of 42 per cent of the firms considered that they had established a better relationship with their subcontractors. The situation of the construction firms was slightly below average in that only 30 per cent of them had established a better relationship with the subcontractors. In general, the study indicated that the relationship between the certified firms and the subcontractors did not change much through the certification exercise.

Some certified firms may have imposed excessive control on the subcontractors. Conversely, some subcontractors, especially the proprietors of small businesses, may be too passive to the new demand for quality. A better approach may be for the certified firms to train and help the subcontractors to understand the importance of understanding the global demand for quality. It was reported that some of the more established firms provided technical assistance to help their subcontractors to implement ISO 9000. This might bean effective means to maintain quality and improve relationships with subcontractors. 


\section{Quality improvement}

In order to find out how the ISO 9000 certified firms would continuously improve quality management, several quality management approaches were listed in the questionnaire and the firms were asked to identify if they

- were planning for it;

- were practising it;

- would not do it; or

- had no idea about it.

The quality management approaches identified in the questionnaire were total quality management (T QM) (Dale, 1994), kaizen (Imai, 1986), ISO 14000 (T ibor, 1996), quality control circles (QCC) (Ishikawa, 1990), Hong Kong Government Quality Award, Q-mark (managed by the Federation of Hong Kong Industries) and Malcolm Baldrige National Quality A ward (USA) (Brown, 1996).

The number and percentage of firms reported to have been planning and practising the management approach concerned were added together for analysis (Table VIII). This survey showed that T QM was the most popular quality management approach. In both the manufacturing and service sectors, 70 per cent of the firms were planning for or practising T QM. T he figure for the construction firms was only 41 per cent; however, this was the highest compared with other aspects in the same sector. A lthough T QM was not fully defined and many TQM methodologies and tools existed, the findings tended to indicate that ISO 9000 certified firms would continue to improve the management of quality. Some firms took up the " $5 \mathrm{~S}$ " $(\mathrm{Ho}, 1996)$ practice as a TQM initiative, while some others paid more attention to quality cost practices.

Training is an important indicator of how well a firm is prepared for quality management. A ccording to the survey, nearly 90 per cent of the certified firms had provided training on ISO 9000 for their senior management, middle management and front line staff. However, only a third of the firms in

\begin{tabular}{|c|c|c|c|c|c|c|c|c|c|}
\hline $\begin{array}{l}\text { Quality } \\
\text { management } \\
\text { approaches }\end{array}$ & \multicolumn{2}{|c|}{ M anufacturing } & \multicolumn{2}{|c|}{ Service } & \multicolumn{2}{|c|}{ Construction } & \multicolumn{2}{|c|}{ All } & \\
\hline TQM & 60 & 70 & 40 & 70 & 38 & 41 & 138 & 59 & \\
\hline Kaizen & 18 & 21 & 14 & 25 & 8 & 9 & 40 & 17 & \\
\hline QCC & 35 & 41 & 20 & 35 & 21 & 23 & 76 & 32 & \\
\hline ISO 14000 & 38 & 44 & 22 & 39 & 33 & 36 & 93 & 40 & \\
\hline $\begin{array}{l}\text { Quality award } \\
\text { (Hong Kong }\end{array}$ & & & & & & & & & Table VIII. \\
\hline Government) & 18 & 21 & 5 & 9 & 14 & 15 & 37 & 16 & Quality management \\
\hline Q-mark & 10 & 12 & 2 & 4 & 4 & 4 & 16 & 7 & approaches taken by \\
\hline Malcolm Baldrige & 3 & 3 & 10 & 18 & 5 & 5 & 18 & 8 & certified firms \\
\hline
\end{tabular}


IJQRM

15,2

172

manufacturing and service sectors had provided T QM training for their staff (T ables IX and X). T he corresponding figures in the construction sector were 20 per cent for the senior management and even lower for the middle management and front line staff. These figures indicated that the firms were not quite ready for T QM . It is believed that greater senior management commitment is required for T QM than for ISO 9000. M ore training on T QM for the staff at all levels will be required for the firms which plan to practise T QM.

\begin{tabular}{|c|c|c|c|c|c|c|c|c|}
\hline \multirow[b]{2}{*}{ TQM training } & \multicolumn{2}{|c|}{ Manufacturing } & \multicolumn{2}{|c|}{ Service } & \multicolumn{2}{|c|}{ Construction } & \multicolumn{2}{|c|}{ All } \\
\hline & & $(\%)$ & $(\mathrm{N})$ & $(\%)$ & & & & $(\%)$ \\
\hline \multicolumn{9}{|l|}{ Senior } \\
\hline $\begin{array}{l}\text { management } \\
\text { Middle }\end{array}$ & 31 & 36 & 21 & 37 & 17 & 20 & 69 & 30 \\
\hline management & 33 & 38 & 23 & 40 & 14 & 16 & 70 & 31 \\
\hline Front line staff & 26 & 30 & 21 & 37 & 8 & 9 & 55 & 24 \\
\hline
\end{tabular}

Table IX.

Total quality management training

\section{ISO 9000 \\ training}

Senior

management

Middle

Table $X$.

ISO 9000 training management
Front line staff

\section{Service}

(N) $(\%)$

(N) (\%)

$(\%)$

$78 \quad 91$

91

$80 \quad 93$

$\begin{array}{ll}75 & 87\end{array}$

$48 \quad 84$

48

$56 \quad 98$

$51 \quad 89$

\section{Construction}

(N) $\quad(\%)$

All

Following T QM, the next most popular aspect was ISO 14000. A $n$ average of 40 per cent of all the firms which had been certified to ISO 9000 were planning to implement ISO 14000. Some were implementing the draft standard before the official standard was published. The data showed that the manufacturing firms were more active in ISO 14000 among the three sectors. In an interview, the managing director of a manufacturing firm told the author that they were implementing ISO 14000 in anticipation of customer requirements and for corporate image promotion. However, further study is required to fully understand the reasons for implementing ISO 14000 and the benefits.

Quality control circles (QCC) have been a popular tool for quality management since the 1960s. This survey showed that the manufacturing and service sectors were rather receptive to QCC with 41 per cent and 35 per cent of the firms respectively implementing this team approach to quality improvement. How ever, only 23 per cent of the construction firms reported to 
have adopted QCC. W hile QCC was an effective team approach to improving product quality and quality management, it was not easy to maintain long-term success without senior management support. QCC activities were more active in some firms compared with others, some were active at the beginning but slowed down afterwards.

The survey findings showed that the other Japanese total quality control tool, kaizen, was less popular in Hong Kong though a few manufacturing firms reported sending their senior management to Japan for kaizen training.

The Federation of Hong Kong Industries has been administering the Q-mark award since 1978. Unlike ISO 9000, the Q-mark is adhered to the product rather than the management system. The survey indicated that the ISO 9000 certified firms did not show much interest in the Q-mark.

The survey also showed that the certified firms did not have much interest in the Hong Kong Government Quality Award and the Malcolm Baldrige National Quality Award (MBNQA). There is only one winner every year for the Hong Kong Government Quality Award. On the other hand, the Hong Kong Management Association (HKMA) has modelled the MBNQA criteria and run the HKM A Quality Award in Hong Kong since 1991. Like the MBNQA, the number of winners for the award is limited. These may be the reasons that have affected the popularity of the quality awards.

The survey results indicated that a large proportion of the ISO 9000 certified firms tended to continue their pursuit of quality. TQM was the most popular approach taken by the certified firms. ISO 14000 appeared to be an important area and it was likely that some ISO 9000 certified firms would take steps to implement the environmental management standard. Generally speaking, the manufacturing and service firms appeared to be more positive tow ards continuous improvement of quality management than the construction firms.

\section{Means of quality management}

Quality management embraces a wide spectrum of concepts and methods (Evans and Lindsay, 1993). In order to find out which concepts were perceived by the ISO 9000 certified firms as important to quality and management, the firms were asked to rank ten contemporary quality management concepts and practices in the order of 1-10 ( $1=$ most important, $10=$ least important $)$. These quality concepts were:

(1) safety management;

(2) leadership;

(3) competitive comparison (e.g. benchmarking);

(4) team work ( e.g. quality control circles);

(5) environmental management (e.g. ISO 14000);

(6) house keeping and plant maintenance (e.g. " $5 \mathrm{~S}$ " programmes);

(7) customer relationship building and management; 
IJQRM

(8) company image building;

15,2

(9) process re-engineering; and

(10) adopting latest technologies.

Some firms did not rank correctly and only 79 valid returns from 174 manufacturing firms, 50 from service firms and 83 from construction firms were recorded. The survey results showed that the top five management concepts were:

(1) customer relationship building and management;

(2) leadership;

(3) team work;

(4) safety management; and

(5) company image building.

The quality management concepts ranked one by the certified firms are shown in Table XI. "Customer relationship building and management" was ranked 1 by 18 manufacturing firms, 15 service firms and 9 construction firms. In the manufacturing and service sectors, the majority of the firms ranked "customer relationship building and management" the highest, followed by "leadership" and "safety". The order of importance changed slightly for construction firms. "Safety management" was regarded as most important by 20 firms, "team work" by 16 firms and "leadership" by 13 firms in the construction sector.

These results seemed to be quite normal because in manufacturing and service sectors the firms had more direct contacts with their customers whereas in the construction sector most projects were obtained through public tendering. A construction firm with poor safety records would face high social pressure, heavy financial penalty and less chance of obtaining new projects.

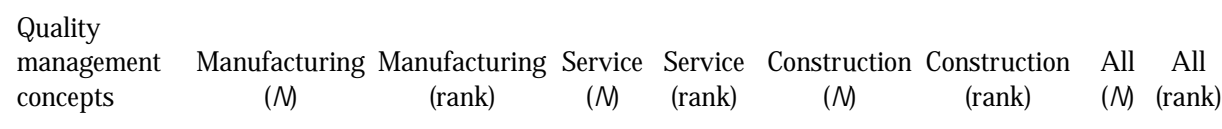

\section{Customer}

relationship

building and

management

Leadership

Team work

Safety

management

Table XI.

Importance of quality management concepts Company

image building

$\begin{array}{cc}18^{\mathrm{a}} & 1^{\mathrm{b}} \\ 17 & 2 \\ 7 & 4\end{array}$

Note: a Number of firms ranking the quality management concept as most important ${ }^{b}$ Ranking of importance of quality management concepts in this sector 
This might explain why safety was regarded the most important factor by the construction firms.

If all the firms' rankings are taken together, the overall ranking was:

(1) customer relationship building and management;

(2) leadership;

(3) safety management;

(4) team work; and

(5) company image building

The manufacturing and service firms were biased towards "customer relationship building and management" and the construction firms placed more emphasis on "safety management". If these two aspects were disregarded, "leadership" appeared to have gained common consensus as the next most important aspect in quality management.

Leadership is a difficult area to address in the sense that leadership does not have a commonly agreed definition in the context of quality management. Furthermore, it is not easy to measure leadership in practice. James MacGregor Burns defines that: "Leadership is leaders including followers to act for certain goals that represent the values and the motivations - the wants and needs, the aspirations and expectations - of both leaders and followers. A nd the genius of leadership lies in the manner in which leaders see and act on their own and their followers' values and motivations." This is regarded as the closest definition of leadership (Phillips, 1992).

In many cases, the decision of implementing ISO 9000 taken by the senior executives and the way they adapted to implement the system do not exhibit a strong leadership style. A s discussed, a larger proportion of the firms were driven by their customers to become certified. Some other firms, typically those in the manufacturing sector, used ISO 9000 as a tool to exercise remote control of the operations in China or elsewhere.

ISO 9000 has been designed as a quality management tool which is able to bring certain benefits to the certified firms. This aspect has been proved and established in this survey. However, if further benefits are to be gained, leadership appears to be an essential factor. This is also established in the survey. The issues of how leadership will affect the success of a firm and what are good leadership styles deserve further elaboration.

\section{Summary and conclusions}

(1) W hile the number of firms seeking ISO 9000 certification was increasing, the proportion of certified small and medium firms remained relatively stable in Hong Kong.

(2) Since 1994, a larger proportion of manufacturing firms employing over 1,000 people had implemented ISO 9000. M ost of these firms used the 
IJQRM

15,2

176 quality assurance management system to control their production and the associated operations in China.

(3) The main reason for small and medium firms in the service sector to become ISO 9000 certified was to satisfy the customers' requirements.

(4) The majority of construction firms were under customer pressure when seeking ISO 9000 certification.

(5) The benefits derived by the certified firms included achieving better team spirit, having fewer staff conflicts, reducing wastage, increasing efficiency, improving sales through attracting new customers, and getting less customer complaints. In general, customer-driven firms obtained less benefits from certification.

(6) One of the biggest limitations of ISO 9000 was that it focused on systematic process management with little emphasis on the use of technology. As a result, it was reported that the certification exercise brought limited improvement on the lead time.

(7) The relationship between the certified firms and subcontractors appeared to be an area where improvement was required. It seemed necessary for the certified firms to provide more training and assistance for the subcontractors in order to upgrade their quality consciousness.

(8) A large proportion of the firms reported having continued their pursuit of quality and management after being certified to ISO 9000. TQM appeared to be the most popular management approach. Some certified firms were planning for ISO 14000 certification.

(9) Customer relationship building and management, leadership, and safety management were ranked as the most important quality concepts.

\section{References}

Brown, M.G. (1996), Baldrige A ward Winning Quality, 6th ed., A SQC Quality Press, Milwaukee, WI.

Dale, B.G. (Ed.) (1994), M anaging Quality, 2nd ed., Prentice-Hall, Hemel Hempstead, Hertfordshire.

Evans, J.R. and Lindsay, W.M. (1993), T he Management and Control of Quality, 2nd ed., West Publishing Co, New York, NY.

Hammer, M. and Champy, J. (1993), Reengineering the Corporation, Harper Business, New York, NY.

Ho, S. (1996), "Japanese 5-S practice in practice", Quality World Technical Supplement, March, pp. 20-4.

Imai, M. (1986), Kaizen: The Key to Japan's Competitive Success, M cGraw-Hill, New York, NY.

Ishikawa, K. (1990), Guide to Quality Control, A sian Productivity Organization, Tokyo.

Lee, T.Y. (1995), "T he experience of implementing ISO 9000 in Hong Kong", A sia Pacific Journal of Quality M anagement, Vol. 4 N 0. 4, pp. 6-16.

Lee, T.Y. (1996), “M anagement strategy for manufacturing industry: kaizen, reengineering or ISO 9000?", Proceedings of Pacific Conference on M anufacturing 1996, Seoul, pp. 417-8. 
Lee, T.Y. (1997), "T he benefits of ISO 9000 certification and future development on quality management", to appear in Proceedings of International Conference on Quality and Reliability ICQR' 97 , Hong Kong.

Mukhi, S., Hampton, D. and Barnwell, N. (1990), A ustralian Management, McGraw-Hill, New York, NY.

Phillips, D.T. (1992), Lincoln on Leadership, Warner Books, New York, NY.

Symonds, J. (1996), "T he M obil Survey: morethan 127,000 ISO 9000 certificates", ISO 9000 News, Vol. 5 No. 6, pp. 1-18.

Development of

ISO 9000

certification

177

Tibor, T. (1996), ISO 14000: A Guide to the New Environmental Management Standards, Irwin, Chicago, IL.

Wenmoth, B.A . and Dobbin, D.J. (1994), "Experience with implementing ISO 9000", A sia Pacific Journal of Quality Management, Vol. 3 No. 3, pp. 9-44. 